\title{
Analysis of RNA splicing defects in PITX2 mutants supports a gene dosage model of Axenfeld-Rieger syndrome Nicole L Maciolek ${ }^{1}$, Wallace LM Alward ${ }^{3}$, Jeffrey C Murray ${ }^{4}$, Elena V Semina*2 and Mark T McNally*1
}

Address: ${ }^{1}$ Department of Microbiology and Molecular Genetics, Medical College of Wisconsin, 8701 Watertown Plank Road, Milwaukee, WI 53226, USA, ${ }^{2}$ Department of Pediatrics, Medical College of Wisconsin, 8701 Watertown Plank Road, Milwaukee, WI 53226, USA, ${ }^{3}$ Department of Ophthalmology, University of Iowa, Iowa City, IA 52242, USA and ${ }^{4}$ Department of Pediatrics, University of Iowa, Iowa City, IA 52242, USA

Email: Nicole L Maciolek - nmaciole@mcw.edu; Wallace LM Alward - wallace-alward@uiowa.edu; Jeffrey C Murray - jeff-murray@uiowa.edu; Elena V Semina* - esemina@mcw.edu; Mark T McNally* - mtm@mcw.edu

* Corresponding authors

Published: II July 2006

BMC Medical Genetics 2006, 7:59 doi:10.1 186/147|-2350-7-59
Received: 03 May 2006

Accepted: II July 2006

This article is available from: http://www.biomedcentral.com/I47I-2350/7/59

(C) 2006 Maciolek et al; licensee BioMed Central Ltd.

This is an Open Access article distributed under the terms of the Creative Commons Attribution License (http://creativecommons.org/licenses/by/2.0), which permits unrestricted use, distribution, and reproduction in any medium, provided the original work is properly cited.

\begin{abstract}
Background: Axenfeld-Rieger syndrome (ARS) is associated with mutations in the PITX2 gene that encodes a homeobox transcription factor. Several intronic PITX2 mutations have been reported in Axenfeld-Rieger patients but their effects on gene expression have not been tested.
\end{abstract}

Methods: We present two new families with recurrent PITX2 intronic mutations and use PITX2c minigenes and transfected cells to address the hypothesis that intronic mutations effect RNA splicing. Three PITX2 mutations have been analyzed: a G>T mutation within the AG 3' splice site (ss) junction associated with exon 4 (IVS4-IG>T), a G>C mutation at position +5 of the 5 ' (ss) of exon 4 (IVS4+5G>C), and a previously reported $A>G$ substitution at position - II of 3'ss of exon 5 (IVS5-I IA>G).

Results: Mutation IVS4+5G>C showed $71 \%$ retention of the intron between exons 4 and 5 , and poorly expressed protein. Wild-type protein levels were proportionally expressed from correctly spliced mRNA. The G>T mutation within the exon 4 AG 3 'ss junction shifted splicing exclusively to a new $A G$ and resulted in a severely truncated, poorly expressed protein. Finally, the $A>G$ substitution at position - II of the 3'ss of exon 5 shifted splicing exclusively to a newly created upstream $A G$ and resulted in generation of a protein with a truncated homeodomain.

Conclusion: This is the first direct evidence to support aberrant RNA splicing as the mechanism underlying the disorder in some patients and suggests that the magnitude of the splicing defect may contribute to the variability of ARS phenotypes, in support of a gene dosage model of AxenfeldRieger syndrome.

\section{Background}

Axenfeld-Rieger syndrome (ARS) is an autosomal-dominant disorder with complete penetrance but variable expressivity, and is one of the developmental conditions of Axenfeld-Rieger spectrum. The spectrum is defined on the basis of specific eye anomalies that include prominent annular white line near the limbus at the level of Descemet membrane (posterior embryotoxon), hypo- 
plastic iris, irido-corneal adhesions and glaucoma [1-5]. Diagnosis of ARS is established when the above-described ocular features are accompanied by other systemic abnormalities, most commonly craniofacial, dental and umbilical defects. Craniofacial anomalies usually consist of maxillary hypoplasia, thin lip and dysplastic ears. Dental defects vary from small teeth to complete anodontia with missing lateral mandibular incisors being the most common feature. Umbilical anomalies may range from isolated redundant skin at the site of the umbilicus to severe hernias or omphalocele. Among other associated anomalies, pituitary and cardiac defects, hearing loss, hydrocephalus and hypospadius have been reported [6-8].

Axenfeld-Rieger spectrum is a heterogeneous condition. Mutations in PITX2 (4q25), FOXC1 (6p25), PAX6 (11p12), and a yet to be identified gene at 13q14 have been shown to result in Axenfeld-Rieger isolated eye anomalies as well as the complete syndrome [9-15]. Ocular manifestations of PITX2 mutations show broad variability, both between and within families. To date, the reported phenotypes include Rieger and Axenfeld anomaly, iris hypoplasia, iridogoniodysgenesis, Peters' anomaly, aniridia and ring dermoid of cornea [9,16-27]. The PITX2 gene encodes a homeodomain-containing transcription factor and spans about $20 \mathrm{~kb}$ of genomic sequence and includes six exons that encode four alternative transcripts that arise by alternative splicing and the differential use of three promoters [28]. Although gain-offunction mutations have been reported $[19,29]$, a deficiency in normal PITX2 protein (haploinsufficiency) is suggested to be the major mechanism of ARS. This is supported by the presence of large deletions that include PITX2 in some Axenfeld-Rieger patients and functional studies of proteins derived from mutant alleles. A correlation between the dosage of normal PITX2 protein and the severity of the phenotype was noted $[19,20,30,31]$. Most of the human PITX2 mutations described thus far affect regions encoding the homeodomain- or C-terminal domains, although a few intronic mutations have been reported (see references above).

Pre-mRNA splicing is the process whereby introns are removed and exons are joined to produce mature mRNA. RNA splicing is facilitated by a large macromolecular machine, the spliceosome, which recognizes conserved sequences at intron/exon borders, including the $5^{\prime}$ and $3^{\prime}$ splice sites and branchpoint sequence [32]. In a few instances, PITX2 mutations have been identified in introns either at or in close proximity to splice sites (ss) associated with the last two exons. These observations suggest that splicing defects might explain the syndrome in these individuals. To date, only coding region mutations in PITX2 have been investigated. Here, we report the identification of two new human families with intronic
PITX2 mutations and present an analysis of the effects of intronic mutations on PITX2 mRNA splicing. The data suggest that aberrant RNA splicing underlies the disorder in six families and that the degree of aberrant splicing may contribute to the variability of Axenfeld-Rieger syndrome phenotypes.

\section{Methods Identification of PITX2 mutations}

DNA samples obtained from new patients with ARS and anomaly were screened for PITX2 gene mutations in exons and at least 100-bp into adjacent intron regions as previously described [9]. DNA was isolated from blood spots using the QIAGEN QIamp ${ }^{\circledR}$ DNA mini kit following the dried blood spot protocol. PCR was conducted in a GeneAmp ${ }^{\circledast}$ PCR system 9700 in $30 \mu \mathrm{l}$ reactions containing 1.5 mmol/l Mg 2+, 40-100 ng DNA, Biolase Reaction Buffer (Bioline), $0.25 \mathrm{mM}$ each dNTP, 1.5 units Biolase DNA polymerase (Bioline) and $0.2 \mu \mathrm{M}$ of each oligodeoxynucleotide primer. Cycling profile was one cycle of $94^{\circ} \mathrm{C}$ for five minutes, 30 cycles of $94^{\circ} \mathrm{C}$ for 45 seconds, $56^{\circ} \mathrm{C}$ for 45 seconds, and $72^{\circ} \mathrm{C}$ for 45 seconds, and one cycle of $72^{\circ} \mathrm{C}$ for ten minutes. Products were either purified using Millipore MultiScreen ${ }^{\circledast}$ Separations System or sequenced directly. Products were sequenced bidirectionally with an ABI Prism ${ }^{\circledast} 3700$ DNA sequencer using ABI Prism ${ }^{\circledast}$ BigDye $^{\mathrm{TM}}$ Terminator Cycle Sequencing Ready Reaction Kits. The $20 \mu \mathrm{l}$ reactions contained 5\% DMSO, $1 \mu \mathrm{l}$ of PCR product DNA, and $0.32 \mu \mathrm{M}$ oligodeoxynucleotide primer. Cycling profile was conducted in a GeneAmp ${ }^{\circledast}$ PCR System 9700. Cycling profile was one cycle of $96^{\circ} \mathrm{C}$ for $30 \mathrm{sec}-$ onds, 35 cycles of $96^{\circ} \mathrm{C}$ for ten seconds, $50^{\circ} \mathrm{C}$ for 5 seconds and $60^{\circ} \mathrm{C}$ for four minutes. Extension products were purified using Agencourt CleanSEQ ${ }^{\circledast}$ Reaction Clean up. PCR products were then sent to Agencourt, Inc to be sequenced. Sequences were manually examined for mutations and confirmed by additional independent amplification and sequencing.

\section{PITX2 DNA constructs}

A primer positioned at g.16944 of the PITX2 genomic sequence (GenBank accession number $\underline{\mathrm{AF} 238048)}$ ) and a downstream primer at g. 17393 were used to PCR-amplify a $473 \mathrm{bp}$ fragment that included part of exon $1 \mathrm{~b}$ and the downstream intron using human genomic DNA as a PCR template; EcoRI and BamHI sites were appended to the 5' and 3 ' ends, respectively. Primers are listed in Table 1. A 653 bp fragment containing exon 4 and surrounding intron was amplified using an upstream primer at position g.17812 (with a 5' BamHI site appended) and a downstream primer at g.18439 containing a 3' KpnI site. A $713 \mathrm{bp}$ fragment containing a portion of exon 5 and the upstream intron was generated using an upstream primer positioned at g.20001 and a downstream primer at g.21147; 5' KpnI and 3' HindIII sites were added to prim- 
Table I: Oligonucleotides used in this study

\begin{tabular}{lll}
\hline Name & Sequence* & Purpose \\
\hline Ex-lb-f & GCGAATTCCAGTAGCCAAGGACTAGTAG & Forward and reverse primers to make exon Ib fragment \\
Int-l b-r & GCGGATCCAGAATTGCTCGCGCCCTTAG & \\
Int-Ib-f & GCGGATCCAGTGAATGTGCCGCTGCAGT & Forward and reverse primers to make exon 4 fragment \\
Int-4-r & GCGGTACCTCGGAGAGGGAACTGTAATC & \\
Int-4-s & GCGGTACCTGGCTGAGTGATCAAACCGT & Forward and reverse primers to make exon 5 fragment \\
Ex-5-r & CGAAGCTTGGCGGCGCGTAAGGACAGG & \\
IVS4+5G>C-f & GAGTCCGGGTAGCAGCCAGCACGGAG & Forward and reverse overlap PCR primers to make IVS4+5G>C mutant \\
IVS4+5G>C-r & CTCCGTGCTGGCTgCTACCCGGACTC & \\
IVS5-IIA>G-f & CTCCCTTGCCCCAgCCGCCCCCAGG & Forward and reverse overlap PCR primers to make IVS5-IIA>G mutant \\
IVS5-IIA>G-f & CCTGGGGGCGGCTGGGGCAAGGGAG & \\
IVS4-IG>T-f & CGTTTTCAtAGAAAGAT & Forward and reverse overlap PCR primers to make IVS4-IG>T mutant \\
IVS4-IG>T-f & ATCTTTCTaTGAAAACG & \\
T7 promoter & TAATACGACTCACTATAGGG & Forward primer to pcDNA T7 promoter to detect minigene mRNA \\
PCREx-Ib-f & TGTCGGCCGTCTCCTCATCTTCC & Forward and reverse primers to detect endogenous and minigene mRNA \\
PCREx-5-r & TTGCGCTCCCTCTTTCTCCATTTG & Forward and reverse primers to GFP \\
GFP-f & GACGGCAACATCCTGGGGCACAAG & \\
GFP-r & CGGCGGCGGTCACGAACTCC & Forward and reverse primers to GAPDH \\
GAPDH-f & TGATGACATCAAGAAGGTGGTGAAG & \\
GAPDH-r & TCCTTGGAGGCCATGTGGGCCAT & \\
\hline
\end{tabular}

*Primers are $5^{\prime}$ to $3^{\prime}$, mutations are in lowercase

ers. Cycling profile was one cycle of $94^{\circ} \mathrm{C}$ for $45 \mathrm{~s}, 30$ cycles at $94^{\circ} \mathrm{C}$ for $45 \mathrm{~s}, 60^{\circ} \mathrm{C}\left(55^{\circ} \mathrm{C}\right.$ for exon $\left.1 \mathrm{~b}\right)$ for $45 \mathrm{~s}$, and $72^{\circ} \mathrm{C}$ for $45 \mathrm{~s}$, and one cycle of $72^{\circ} \mathrm{C}$ for $10 \mathrm{~min}$. Fragments were inserted individually into pGEM-3Z (Promega) using the same restriction sites, and plasmids were sequenced using an ABI PRISM BigDye Terminator v3.1 cycle sequencing kit (Applied Biosystems). Using the appended restriction sites, exon/intron fragments were excised from pGEM-3Z and shuttled sequentially into the same sites of pcDNA3.1/myc-His(-)A (Invitrogen) to create the PITX2C minigene (Figure 2B). Mutant minigenes were constructed by overlap PCR using the above pGEM$3 Z$ constructs as template [33]. Sense and antisense primers containing the desired mutations were used with the appropriate outside primer for PCR to synthesize halfsubstrates. Mutant exon fragments were inserted into pGEM-3Z and mutations were verified by DNA sequencing. The mutant fragments were then used to replace the WT fragment in the minigene construct as described above. N-terminal FLAG-epitope tagged minigenes were constructed by excising the entire minigene from the pcDNA constructs using SalI and a partial EcoRI digestion, and shuttling the fragments into the same sites of $\mathrm{p} 3 \mathrm{X}$ FLAG CMV 7.1 (Sigma).

\section{Transfection and RNA analysis}

HEK293 and HeLa cells were grown in minimal essential growth medium supplemented with $10 \%$ fetal calf serum. Human cornea stromal cells were grown in Dulbecco's modified Eagle medium supplemented with $10 \%$ fetal calf serum. Cells were grown to about $60 \%$ confluence in $6 \mathrm{~cm}$ dishes (HEK293 and HeLa) or 6 well plates (cornea stromal cells) and transfected with $2 \mu \mathrm{g}$ of minigene DNA and $0.5 \mu \mathrm{g}$ GFP using the calcium phosphate method (Amersham Biosciences) for HEK293 and HeLa cells, or Lipofectamine (Invitrogen) for cornea stromal cells. Total RNA was harvested $48 \mathrm{~h}$ later using the Qiagen RNeasy kit. For RT-PCR, reverse transcription was performed on $1 \mu \mathrm{g}$ of total RNA using oligo dT in a volume of $25 \mu \mathrm{l}$. For PCR, $2.5 \mu \mathrm{l}$ of the reverse transcription mixture was used in a 25 $\mu$ PCR reaction using the T7 primer to pcDNA3.1/mycHis(-)A vector and to exon 5 (for minigene mRNA) or to exon $1 \mathrm{~b}$ and exon 5 (for endogenous plus minigene mRNA), and primers to GFP or cellular GAPDH. Cycling conditions were one cycle of $94^{\circ} \mathrm{C}$ for 45 seconds, 30 cycles of $94^{\circ} \mathrm{C}$ for 45 seconds, $60^{\circ} \mathrm{C}$ for 45 seconds, and $72^{\circ} \mathrm{C}$ for 45 seconds, and one cycle of $72^{\circ} \mathrm{C}$ for 45 seconds. To evaluate the accuracy of splicing of WT and mutant mRNA, RT-PCR products were cloned and sequenced. RT-PCR products were blunted with Klenow fragment and then digested with EcoRI, which cuts at a site located upstream of exon $1 \mathrm{~b}$. The products were inserted into the EcoRI and SmaI sites of pGEM-3Z and individual clones were sequenced. To assess minigene splicing by RNase protection assay, a 700 bp riboprobe was made by in vitro transcription using T7 polymerase and HindIII-linearized pGEM-3Z containing the exon/ intron 4 fragment. This includes $264 \mathrm{nt}$ and $183 \mathrm{nts}$ of upstream and downstream intron, respectively, that flank the $206 \mathrm{nt}$ exon 4. A $371 \mathrm{nt}$ GFP riboprobe was made using SP6 polymerase and EcoRI-linearized pGEM-3Z containing a GFP fragment. RNase protection assays were carried out as described previously [34] using $2.5 \mu \mathrm{g}$ RNA. Correct splicing generates a $\sim 206$ nt protected band and 
intron retention yields a $\sim 386 \mathrm{nt}$ band. The GFP probe generates a 309 nt protected band. Results were visualized by autoradiography and quantitated with a Storm 820 PhosphorImager (Amersham Biosciences).

\section{Western Blotting}

HEK 293 cells were transfected with $2 \mu \mathrm{g}$ p3X-FLAG minigene DNA and $1 \mu \mathrm{g}$ pEGFP as described. Cells were washed with phosphate buffered saline, harvested by scraping, the cells were resuspended in water, an equal volume of $2 \times$ solubilizing buffer ( $2 \%$ SDS, $10 \% \beta$-mercaptoethanol, 5\% glycerol, $50 \mu \mathrm{M}$ Tris, $\mathrm{pH} 7,0.005 \%$ bromphenol blue) was added, and samples were sonicated for five seconds. Samples were subjected to $10 \%$ SDS-PAGE and transferred to nitrocellulose membrane by electrotransfer. Immunoblotting was done as described [33], blots were blocked with nonfat dry milk, incubated with anti-FLAG M2 monoclonal primary antibody (Sigma) or anti-GFP monoclonal primary antibody (Covance), and after washing, goat anti-mouse IgM $\mu$ HRP-conjugate secondary antibody (Upstate) was applied. Blots were developed using Supersignal West Pico Chemiluminescent Substrate (Pierce). Results were visualized by autoradiography or images were obtained using a Fluorchem IS-8800 (Alpha Innotech).

\section{Results \\ Identification of two new families with intronic PITX2 mutations}

DNA samples obtained from new patients with AxenfeldRieger syndrome and anomaly were screened for mutations in exons and at least 100-bp in the adjacent intron regions. Two new families with intronic PITX2 mutations have been identified. The first mutation was identified in a patient (0175) affected with ARS (Figure 1A). The patient displayed all classic features of this condition and some additional defects: Rieger anomaly of the eye, widespaced eyes, thin upper lip, hypoplastic maxilla, dental defects, redundant periumbilical skin, and an anteriorly placed anus. The mutation identified in this patient is a $\mathrm{G}>\mathrm{T}$ change in the -1 position of the 3 ' ss associated with exon 4 (IVS4-1G>T) (g.18072G $>\mathrm{T}$ as seen in PITX2 sequence GenBank \# AF238048; Figures 1A and 2C). Both parents display a normal phenotype; testing of the patient's mother confirmed normal PITX2 sequence (data not shown) and the father was not available for testing. This mutation was reported previously in an ARS patient with severe ocular malformations, underdeveloped maxilla and redundant umbilical skin [25]. Perveen et al. [18] reported a $\mathrm{G}>\mathrm{C}$ mutation at the same position and affected individuals from this family demonstrated severe ARS phenotypes: severe iris hypoplasia emulating aniridia in one patient and joint hypermobility and an anteriorly placed anus in another individual were reported.
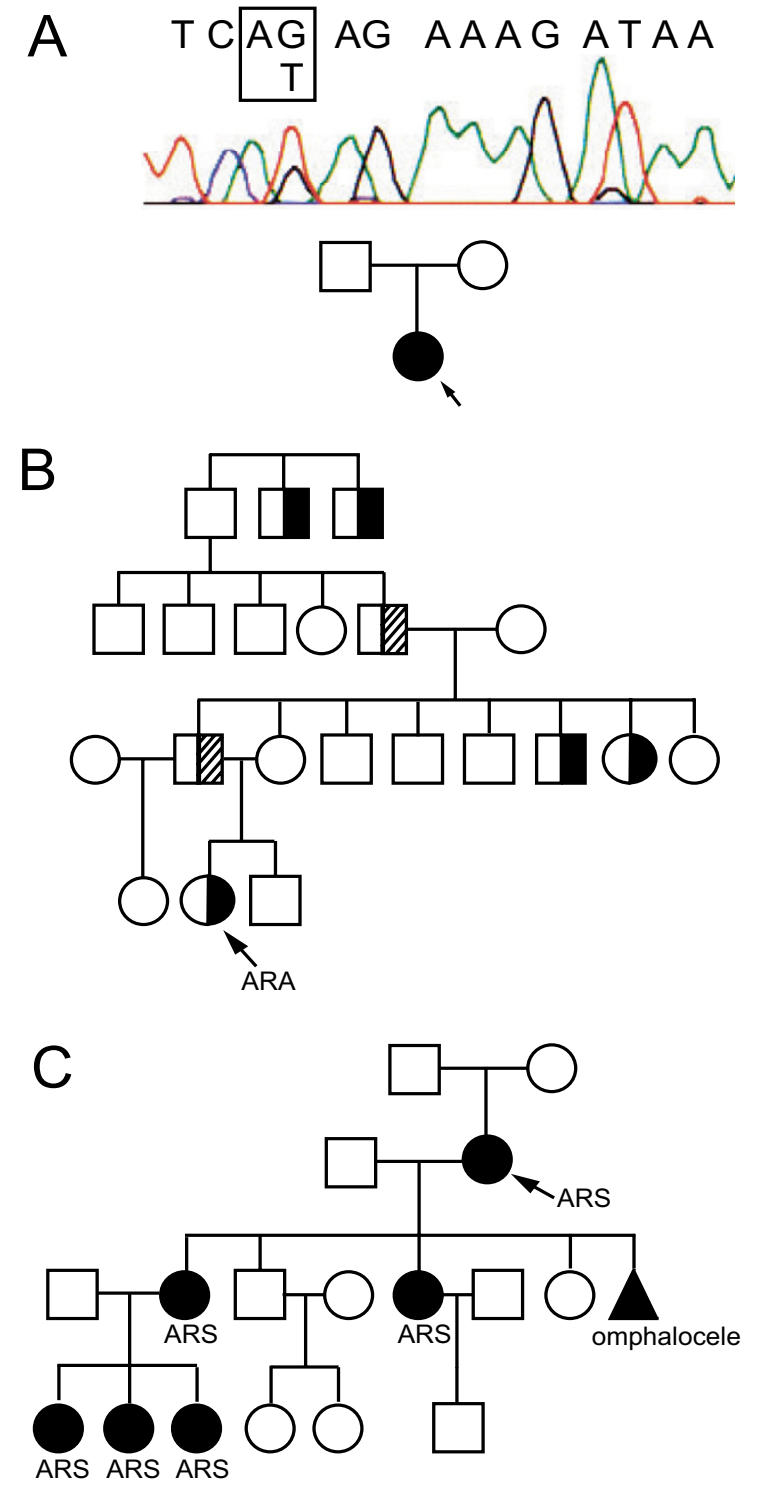

Figure I

Axenfeld-Rieger pedigrees with intronic mutations in PITX2. A. Pedigree of family $0 I 75$ and sequence of genomic DNA of the patient showing an intronic mutation in the AG dinucleotide at the 3 ' ss splice junction of exon 4 (boxed). Proband is indicated with an arrow. B. Pedigree of family 689. Proband is indicated with an arrow. Individuals affected with an isolated ocular phenotype according to family history are indicated by half-shaded circles or boxes. Individuals affected with subclinical phenotypes who are likely mutation carriers are indicated with half-striped boxes. ARA, Axenfeld-Rieger anomaly. C. Pedigree of family 2 with clinical features.

Proband is indicated with an arrow. Individuals affected with classic Axenfeld-Rieger syndrome (includes the triad of ocular, dental and umbilical anomalies) are indicated as shaded circles or boxes. ARS, Axenfeld-Rieger syndrome. The shaded triangle indicates a miscarriage of a child of unknown sex. 
The second mutation was found in patient 689 , who displayed Axenfeld-Rieger anomaly in one eye only and no craniofacial, dental or umbilical abnormalities. The patient had normal ocular pressure and vision, the right eye had a posterior embryotoxon visible on slit lamp exam with iris sheets sweeping up to the embryotoxon inferiorly, and no iris hypoplasia was noted. Slit lamp exam of the left eye demonstrated normal development. Clinical family history of this patient contains records of developmental ocular defects but dental or umbilical anomalies were never noted (Figure 1B). The mutation was identified as a $\mathrm{G}>\mathrm{C}$ substitution at the +5 position of the $5^{\prime}$ ss of PITX2 exon 4 (IVS4+5G $>C$ ) $($ g. $18283 \mathrm{G}>\mathrm{C}$ as seen in PITX2 sequence GenBank \# AF238048; Figures 1B and $2 \mathrm{C}$ ). The same change was previously reported in a patient affected with the complete ARS [9]. Collection and examination of clinical information from this family indicated a substantial family history of complete ARS (pedigree and clinical diagnoses are shown in Figure 1C).

Analysis of PITX2c RNA splicing using a minigene construct Most Rieger syndrome patients have point mutations in the coding region of PITX2 [9] and most of these affect the DNA binding homeodomain [35]. Previous work and the data above brings to eight the number of families with mutations that do not affect the protein coding potential of the gene, and the number of different mutations is now five $[9,17,18,21,25]$. We set out to examine three recurrent intronic mutations, each of which was described in two unrelated families of Axenfeld-Rieger spectrum, and to correlate the phenotypes with potential molecular defects in pre-mRNA splicing. The IVS4-1G $>$ T and IVS4+5G $>C$ mutations were described above. A third mutation studied was an $A>G$ change $11 \mathrm{nt}$ upstream of the 3 'ss of exon 5 (IVS5-11A $>$ G) that was originally described in family 4 by Semina et al. [9] and later by Borges et al. [21] who reported the same change in another family (family 5); both families displayed classic features of ARS.

The PITX2 gene is located at 4q25 and numerous isoforms are produced through the use of alternative promoters and extensive alternative splicing of the six exons (Figure 2A) [28]. PITX2 is expressed developmentally and in some adult tissues but not blood (EVS, unpublished) and thus patient samples to analyze splicing directly are not readily available. To overcome this limitation, a minigene for expression in tissue culture cells was designed that included the exons that comprise one of the common PITX2 isoforms, PITX2c, (Figure 2B) [36]. Since the signals required for constitutive splicing are usually within $\sim 100$

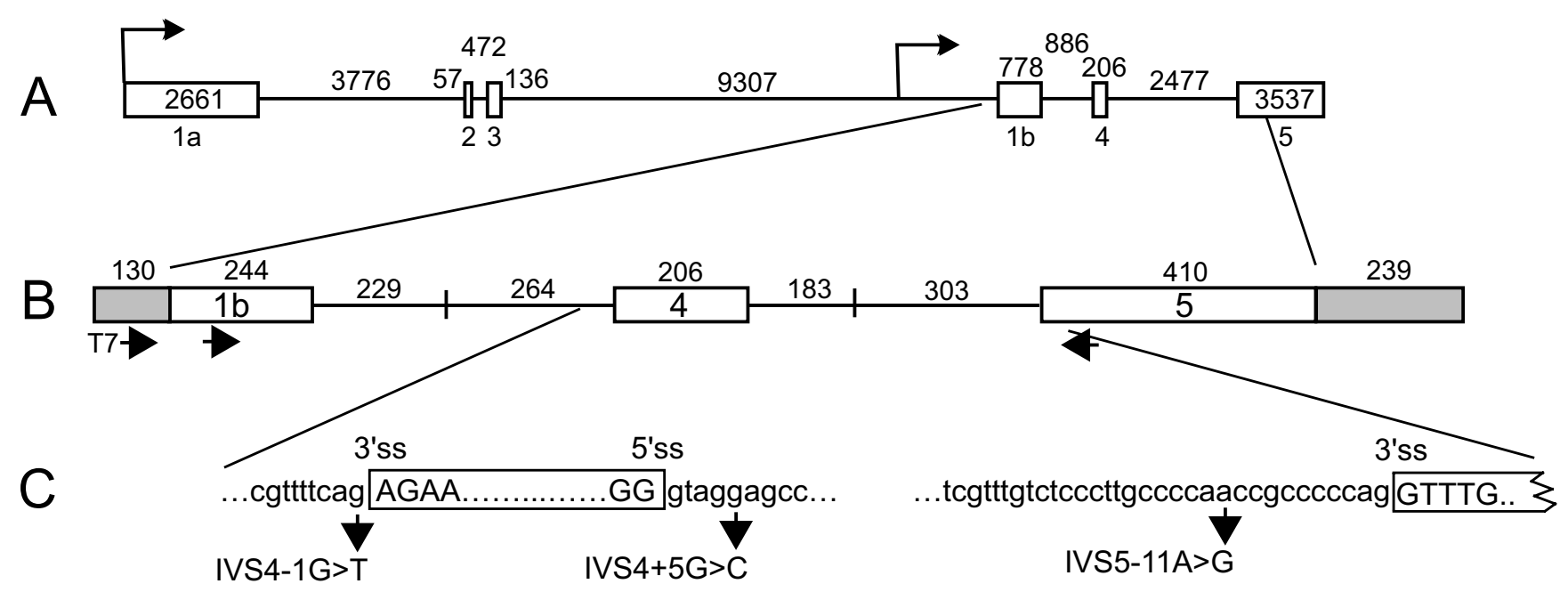

Figure 2

PITX2 gene and minigene structure. A. Schematic of PITX2 gene organization (drawn to scale). Open boxes represent exons, lines represent introns. The sizes of exons and introns are shown. The PITX2 gene has two major promoters (arrows) and six exons. Alternative splicing and transcription start sites give three major isoforms (not shown). PITX2c uses the downstream promoter and produces an mRNA containing exon Ib, 4, and 5. B. Schematic of PITX2c minigene. The minigene contains a portion of exon $\mathrm{Ib}$, exon 4, part of exon 5 , and uses the CMV promoter and bGH polyadenylation site from the PcDNA3.I/myc-His(-)A vector (transcribed vector sequences are represented by shaded boxes). The lengths of intron regions associated with each exon are shown with vertical lines indicating the fusion of two fragments. The positions of the T7 primer to vector sequences, and primers to PITX2 exons $\mathrm{Ib}$ and 5 that were used for RT-PCR are shown below the diagram. C. Expansion of (B) showing the names and locations of three different intronic point mutations identified in ARS patients. The sequence surrounding the $5^{\prime}$ and $3^{\prime}$ splice sites of exon 4, and the 3 ' ss of exon 5 is shown. Mutations in patients 0 I75 (IVS4IG>T), 689 or 2 (IVS4+5G>C), and 4 (IVS5-I IA>G) are indicated by arrows and the nucleotide changes are shown. 
nucleotides of splice junctions [32,37], the introns were truncated to facilitate DNA cloning. Because there is no evidence that the extensive 5 ' and 3 ' untranslated regions are needed for constitutive splicing, exons $1 \mathrm{~b}$ and 5 were also truncated; exon 1b starts $40 \mathrm{nt}$ upstream of the translation start codon and the exon 5 fragment ends with the last amino acid codon. Minigene splicing was analyzed in HeLa and HEK293 cells since they have been used extensively to study constitutive RNA splicing. Additionally, cornea stromal cells (generously provided by Dr. Watsky, University of Tennessee) [38] were used since PITX2 is expressed during corneal development and this cell line endogenously expresses PITX2, and thus may more faithfully reproduce PITX2 splicing that occurs in patients.

HeLa and HEK293 cells were mock transfected or transfected with $2 \mu \mathrm{g}$ of minigene DNA and/or a GFP-expressing transfection control plasmid and RT-PCR was performed on RNA isolated 40-48 h later. While PITX2c is not expressed in these cell types (data not shown), to ensure that only minigene RNA was detected, an upstream primer complementary to vector sequence was used in combination with a primer specific to PITX2 exon 5. Correct splicing would result in a 585 bp RT-PCR product whereas unspliced RNA would produce a 1564 bp product. The 585 bp band was observed only from transfected HEK293 cells and analysis of GFP expression demonstrated equivalent transfection efficiency and gel loading (Figure 3A, lanes 2 and 3). Similar results were obtained with HeLa cell RNA (data not shown). These results suggest that the HeLa and HEK293 cells faithfully express correctly spliced minigene RNA. As an additional test to verify the utility of the minigene, human cornea stromal cells were similarly examined. The primer pair specific for the minigene resulted in the $585 \mathrm{bp}$ spliced product only in transfected cells (Figure 3B, lanes 2 and 3, top) whereas a primer pair that does not distinguish between transfected and endogenous PITX $2 c$ mRNA produced a $404 \mathrm{bp}$ product that was present in both but more abundant in transfected cells, consistent with correct splicing of endogenous and transfected PITX2 mRNA in corneal cells (lanes 2 and 3, middle). Analysis of cellular GAPDH showed equal sample loading (Figure 3B, bottom).

To further assess the accuracy of minigene mRNA splicing in HEK293 and human cornea stromal cells, the RT-PCR products were cloned and three and four independent clones were sequenced, respectively. Each sequence showed correct minigene splicing (Figure 3C). These data indicate that the PITX2c minigene was efficiently and accurately spliced and therefore validated the system for determining the effects of patient mutations on RNA splicing. This system would not address potential tissuespecific splicing defects that may be important for ARS.

\section{A G>T mutation at the 3' splice site of exon 4 shifts splicing 2 nt downstream}

Patient 0175 reported here and patient 2 previously described by Lines et al. [25] display severe features of ARS (see above) and harbor a $\mathrm{G}>\mathrm{T}$ mutation in the -1 position of the 3 ' ss of exon 4 mutation (IVS4-1G $>$ T) (Figures 1A and $2 \mathrm{C}$ ). This changes the canonical "AG" acceptor splice site to an "AT". In addition, a G>C substitution at the same site was previously reported in a patient that displayed classic ARS $[18,25]$. To test the effect of the $G>T$ mutation on splicing, the three cell lines were transfected with WT or IVS4-1G $>$ T minigenes and the splicing status of the mRNA was analyzed by RT-PCR. A single RT-PCR product of the appropriate size for correctly spliced RNA was observed with HEK293 (Figure 4A, top, lane 3), cornea stromal (bottom, lane 7), and HeLa cell RNA (not shown). A GFP-expressing plasmid used as a transfection and RNA loading control showed equal loading in each case (Figure 4A). To examine the possibility that a subtle change in splicing occurred that was not obvious from the size of the RT-PCR product, the PCR products were cloned and 13 HEK293 and three cornea cell independent clones were sequenced. All sequences showed that splicing was shifted 2 nt downstream to the next available "AG" dinucleotide (Figure 4B). Based on the results with the minigene in cultured cells, it is likely that all PITX2 mRNA from this allele is incorrectly spliced in these patients.

\section{A G>C mutation 5 nt downstream of the 5 ' splice site of exon 4 results predominantly in intron retention}

The $\mathrm{G}>\mathrm{C}$ mutation at the +5 position of the 5 'ss of exon 4 , IVS4 $+5 \mathrm{G}>\mathrm{C}$, was originally described in a family with ARS [9] and above we described the same mutation in a patient 689 with an isolated Axenfeld-Rieger anomaly. To assess the effect of this mutation on splicing, HeLa, HEK293, and human cornea stromal cells were transfected with wild type (WT) or mutant minigenes and GFP, and the isolated RNA was analyzed by RT-PCR. As shown in Figure 5A for HEK293 and cornea stromal cells, a band of the size expected for correctly spliced RNA was again observed from the WT minigene (lanes 2 and 5 ) but two RT-PCR products were seen with IVS $4+5 \mathrm{G}>\mathrm{C}$ (lanes 3 and 6 ). The lower band size was consistent with correctly spliced minigene RNA whereas the second product was larger but not the expected size for completely unspliced RNA. Analysis of GFP showed equal loading for each sample (Figure 5A). Similar results were seen with HeLa cell RNA (data not shown).

To determine the nature of the aberrant PCR product observed from the IVS4+5G>C minigene, both RT-PCR products from HEK293 RNA were cloned and independent clones of six large products and eleven 585 bp products were sequenced. The sequences showed that the lower band of IVS4+5G>C RNA was derived from cor- 

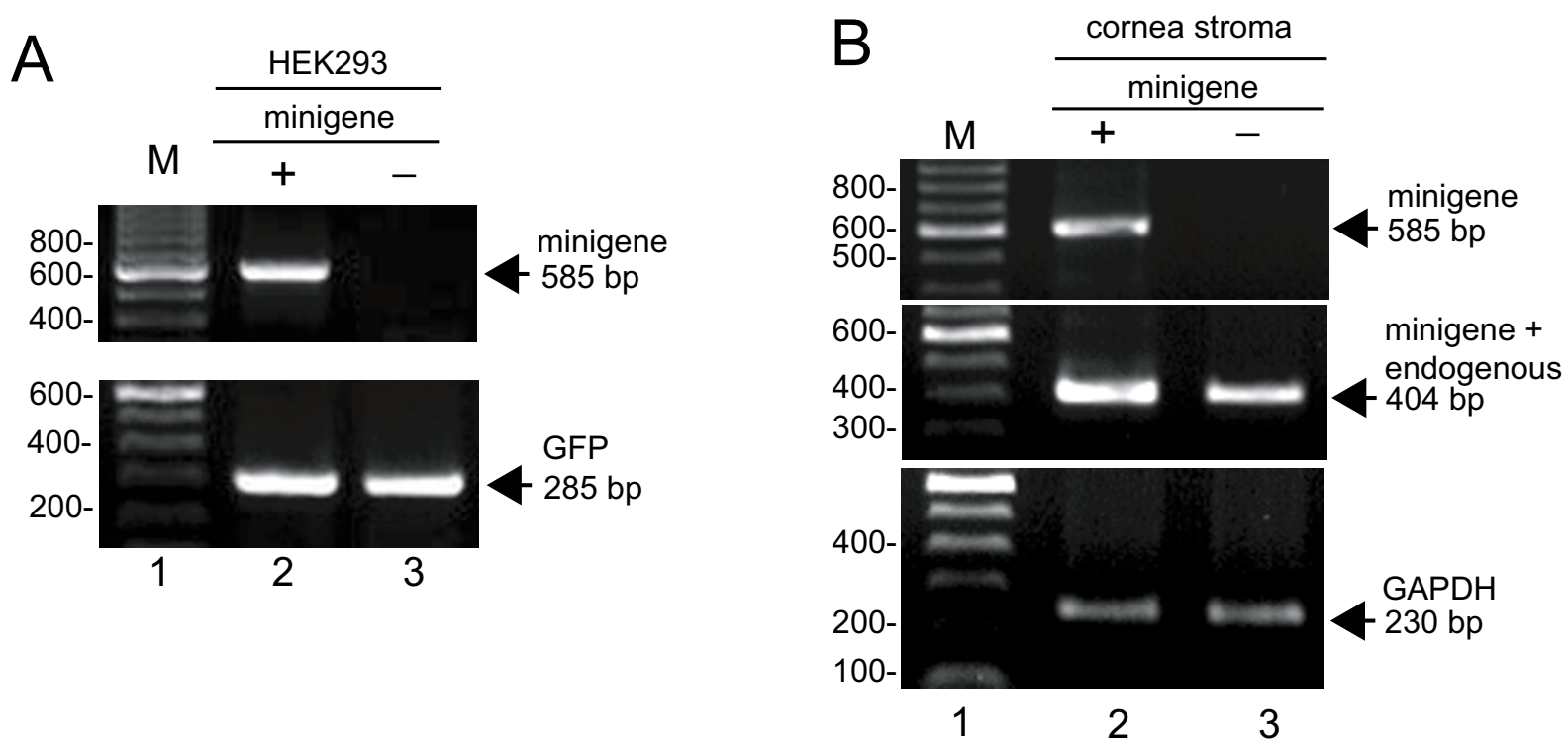

C

4 5

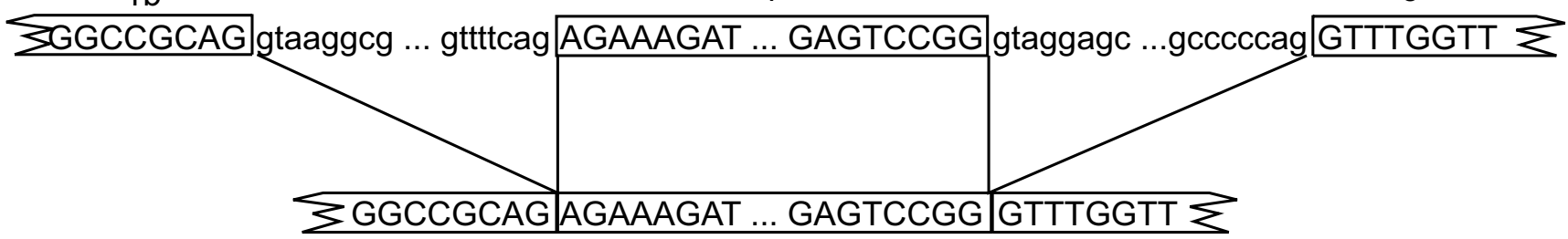

\section{Figure 3}

The PITX2c minigene is expressed and the mRNA splices normally. A. HEK293 cells were transfected with a GFP transfection control plasmid with (+) or without (-) $2 \mu \mathrm{g}$ of the minigene. Transfected-cell RNA was isolated and subjected to RT-PCR with primers to the minigene (top) or GFP (bottom) and the products were resolved on an agarose gel. The position of correctly spliced product for the minigene and GFP is shown at the right. M, 100 bp size standards with selected sizes shown. B. Human cornea stromal cells were either mock transfected (-) or transfected with $2 \mu \mathrm{g}$ of minigene DNA (+). RNA was isolated and analyzed by RT-PCR with primers that amplify only minigene mRNA (top) or those that amplify both minigene and endogenous PITX2c mRNA (middle), or to cellular GAPDH (bottom), and products were resolved on an agarose gel. Primers are depicted in Figure 2B. M, 100 bp size standards with selected sizes shown. The positions of correctly spliced products are shown at the right. C. Sequence of spliced products. RT-PCR products were cloned and sequenced. At the top is a schematic of the pre-mRNA with exon sequences boxed and in uppercase and intron sequences in lowercase. Lines extend from splice sites to the spliced product sequence shown at the bottom.

rectly spliced mRNA and that the upper band retained the intron between exons 4 and 5 (Figure 5B).

To accurately quantitate the frequency of intron retention in IVS4+5G>C RNA, an RNase protection assay (RPA) was performed using a 700-nt riboprobe that spanned the 206 nt exon 4 and included upstream and downstream intron sequences. Correctly spliced RNA results in a 206 nt protected band while retention of the intron would yield a $386 \mathrm{nt}$ band (Figure 5C). RNA from the WT minigene was virtually completely spliced (Figure 5D, lane 4) whereas approximately $71 \%$ of the RNA from IVS $4+5 \mathrm{G}>\mathrm{C}$ retained the second intron (Figure 5D, lane 5). Thus, mutation
IVS4+5G>C causes significant disruption in PITX2c minigene splicing.

\section{An A>G mutation I I nt upstream of the 3' splice site of exon 5 shifts splicing to that site}

The previously reported patients from family 4 [9] and family 5 [21] have classic ARS and harbor an A>G mutation 11 nt upstream of the 3 ' ss associated with PITX2 exon 5 (mutation IVS5-11A>G) (g.20745A $>\mathrm{G}$ as seen in PITX2 sequence GenBank \# AF238048; Figure 2C). To determine if this mutation affects splicing, HeLa, HEK293 and human cornea stromal cells were transfected with the WT or IVS5-11A $>\mathrm{G}$ minigenes and the isolated RNA was 
A

HEK293
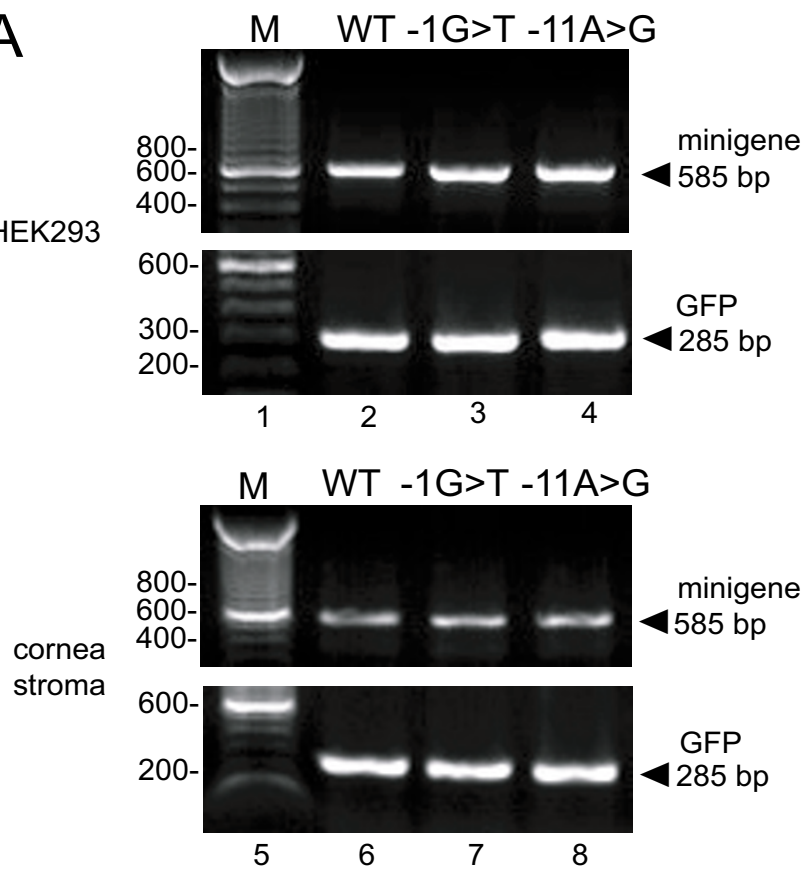

B

wild type: ...ttcag AGAAAGATAAAAGCCAG ...

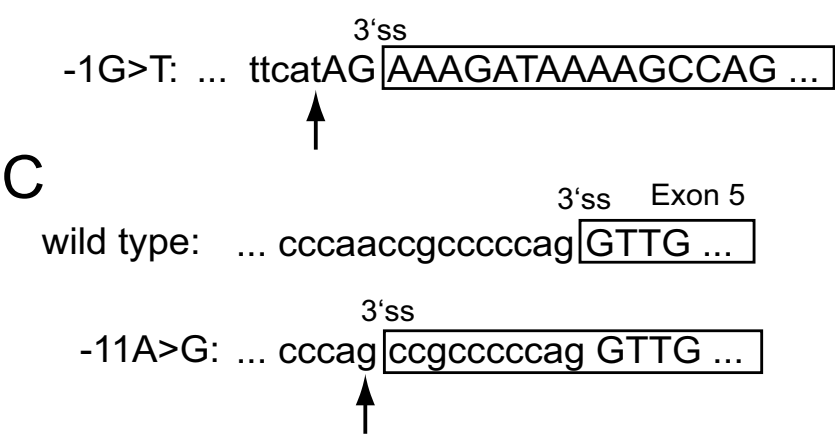

Figure 4

Mutants IVS4A-I T and IVS5-I I A>G splice aberrantly. A. Analysis of transfected-cell RNA by RT-PCR. RNA from HEK293 cells (lanes 2-4) or human cornea stromal cells (lanes 6-8) transfected with GFP and the indicated minigene was analyzed by RT-PCR and products were resolved on an agarose gel. The position of correctly spliced minigene product (585 bp) and GFP is shown at the right. M, 100 bp size standards with selected sizes shown. WT, RNA from wild type minigene; - IG>T, RNA from mutant IVS4-IG>T minigene; - I $\mid A>G$, RNA from mutant IVS5- I I A > G minigene. $B$. Schematic of the 3'ss used in the IVS4-IG>T RT-PCR products from (A) that were cloned and sequenced. $C$. Schematic of the RNA sequence of patient IVS5-I IA>G RT-PCR products from $(A)$ that were cloned and sequenced. In $B$ and $C$, exon sequences are boxed and in uppercase, intron sequences are in lowercase, and an arrow points to the patient mutation. analyzed by RT-PCR. The RT-PCR product from IVS5$11 \mathrm{~A}>\mathrm{G}$ RNA was the same size as correctly spliced PITX2c mRNA (Figure 4A, lanes 4 and 8 ). PCR of GFP served as a loading control. To determine if the mutation caused an aberrant splice that did not alter the RT-PCR product size appreciably, the RT-PCR product was cloned and 11 independent HEK293 clones were sequenced. All of the sequences showed that splicing was shifted exclusively to the newly created "AG" dinucleotide acceptor site $11 \mathrm{nt}$ upstream of the authentic 3' ss (Figure 4C). Based on these results, it is likely that PITX2 mRNA from this allele is always incorrectly spliced in these patients.

\section{Analysis of PITX2c protein expression}

Aberrantly spliced mRNA derived from the mutant patient PITX2 genes is expected to result in truncated PITX2c protein since frameshifts occur in each case (Figure 6A). PITX2 protein levels were determined in transfected cells by western blot (Figure 6B) after normalizing protein levels to GFP expression and RNA expression as determined by RPA. RPA analysis demonstrated that mRNA expression was roughly similar for each minigene (Figure 6C) and that, except for IVS4+5G>C, each minigene mRNA was doubly spliced (although aberrantly).

The WT minigene produced a protein of the expected size, $\sim 36 \mathrm{kDa}$ (Figure 6B, lane 1). The IVS4-1G>T minigene produced a much smaller protein ( 12 kDa, lane 4), but this was expected since this protein would terminate at a single frame-shifted amino acid after PITX2 position 70. It appears that the IVS4-1G $>$ T protein is unstable since it was present at only $5 \%$ of WT levels, despite its mRNA being at least as abundant as WT. The IVS4 $+5 \mathrm{G}>\mathrm{C}$ mRNA generated a normal sized protein and a second product of the size $(\sim 29 \mathrm{kDa})$ appropriate for truncated protein derived from intron-containing mRNA (lane 2); when corrected for mRNA levels, the truncated protein was about one tenth the abundance of normal protein. It was also evident that the level of normal protein expressed from the IVS4+5G>C minigene was roughly proportional to correctly spliced mRNA levels, which was about $30 \%$ of that produced from the WT minigene. Conversely, the level of truncated protein generated from the intronretaining mRNA ( $~ 71 \%$ of minigene RNA produced) was considerably less than expected if protein expression was proportional to mRNA. These data are consistent with inefficient export of the intron-containing IVS $4+5 \mathrm{G}>\mathrm{C}$ mRNA from the nucleus. However, the possibility that the mRNA is exported but not translated, or exported but produces an unstable protein, cannot be excluded. Finally, the IVS5-11A $>$ G mRNA would direct synthesis of a protein containing 138 residues of PITX2 followed by 117 frame-shifted amino acids and again, an expected $\sim 33$ $\mathrm{kDa}$ protein was expressed (lane 3 ) at a level similar to WT. 


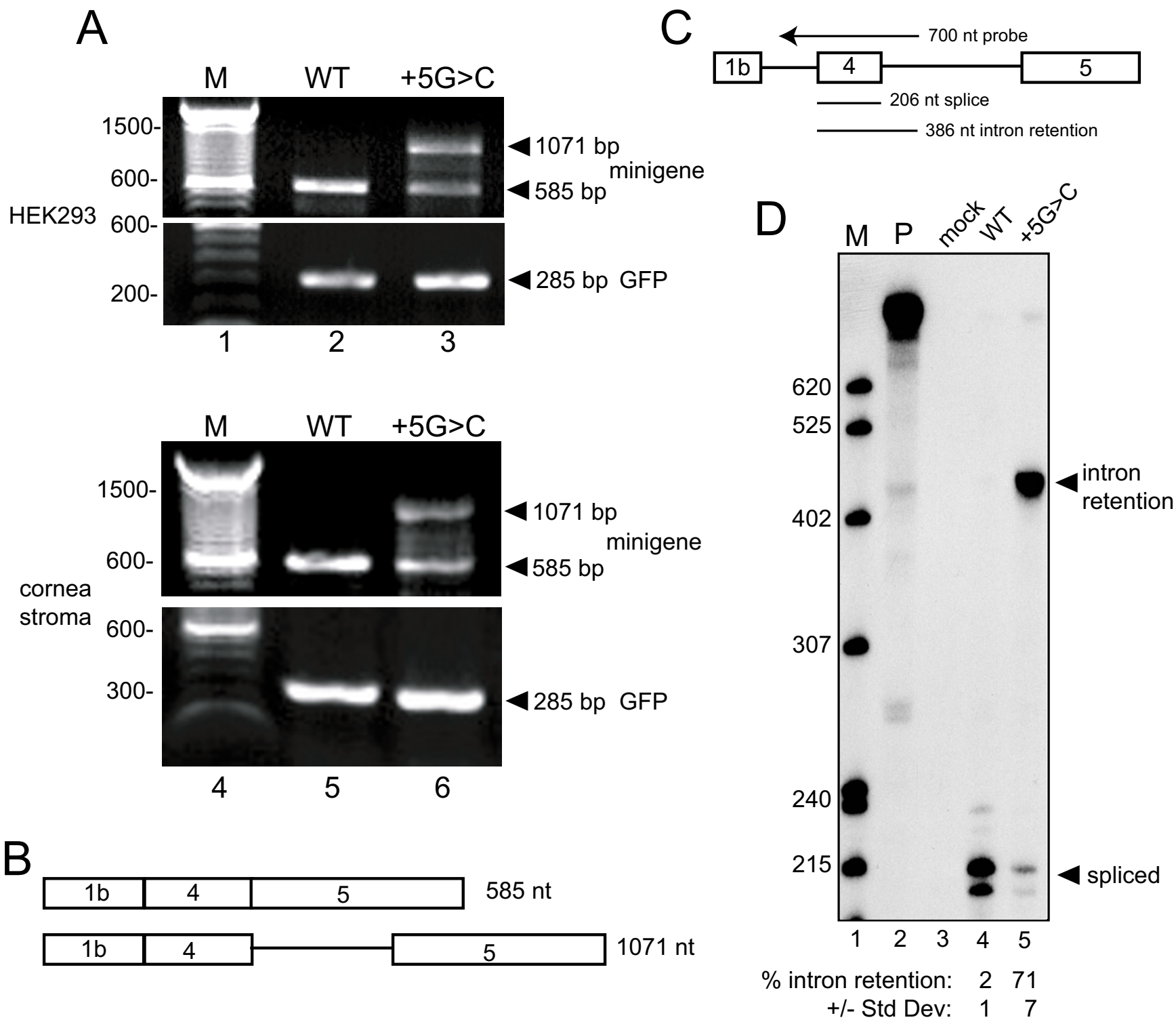

\section{Figure 5}

The IVS4+5G>C mutation causes intron retention. A. RNA from HEK293 cells (lanes 2 and 3) or human cornea stromal cells (lanes 5 and 6) transfected with WT or IVS4+5G>C minigenes and GFP was subjected to RT-PCR and products were resolved on an agarose gel. The positions of correctly spliced (585 bp), intron retention (I07I bp), and GFP products are shown at the right. M, 100 bp size standards with selected sizes shown. B. Diagram depicting the RNA structure of RT-PCR products from $(A)$ that were cloned and sequenced. At the top is correctly spliced RNA, the bottom is RNA that retains the intron downstream of exon 4. C. Schematic of the RNase protection probe and protected products observed in D. The sizes of the probe and protected products are indicated. D. RNase protection assay (RPA). HEK293 RNA was subjected to RPA, protected products were resolved on a 6\%-8 $\mathrm{M}$ urea polyacrylamide gel, and a phosphorimage is presented. Correct splicing generates a $\sim 206 \mathrm{nt}$ band and intron retention gives a $\sim 386 \mathrm{nt}$ band. M, 32P-labeled pBR322/Mspl markers with sizes indicate on the left; P, undigested probe; mock, RPA using RNA from untransfected cells; WT, RNA from WT minigene-transfected cells; +5G>C, RNA from mutant IVS4+5G>C minigene-transfected cells. The positions of correctly spliced and intron retention protected products are shown at the right. The doublet bands for spliced product are likely due to incomplete RNase digestion. Below the lanes is quantitation of \% intron retention (+/- standard deviation) as assessed by Phosphorlmager analysis $(n=17)$. 


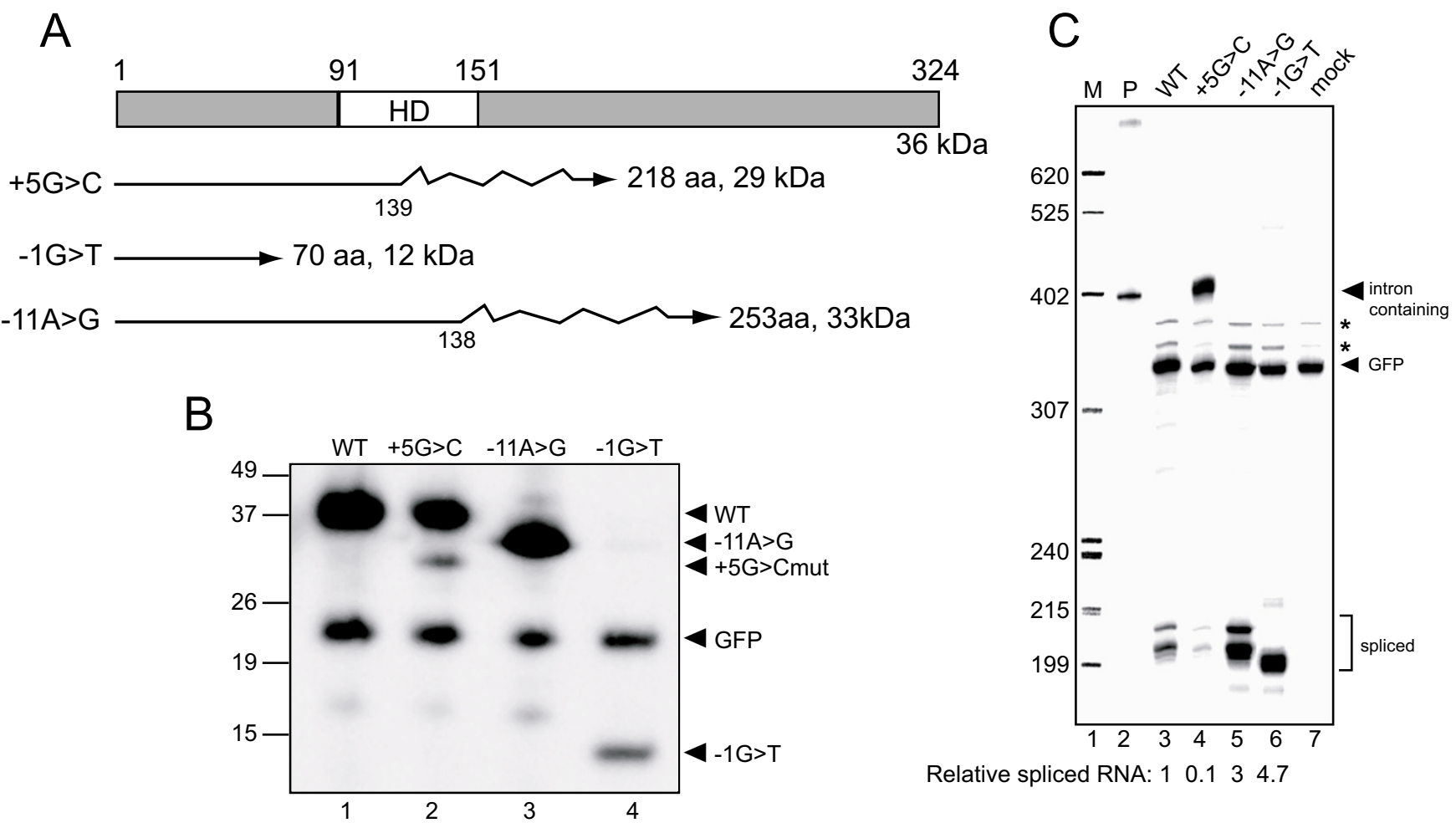

Figure 6

Analysis of protein expression from mutant minigenes. A. The domain structure of PITX2c protein with the position of the homeodomain (HD) is shown. Lines below represent the proteins that would result from aberrantly spliced RNA caused by each of the mutations. Straight lines indicate normal protein and jagged lines indicate incorrect amino acids generated by frame shifts; the number of normal amino acids and full-length size is shown for each. B. Western blotting of indicated FLAG epitope-tagged PITX2c and GFP proteins expressed in HEK293 cells. WT, protein from a wild type minigene transfection; +5G>C, protein from IVS4+5G>C mutant minigene transfected cells; - I IA>G, protein from IVS5-I IA>G mutant minigene transfection; - IG>T, protein from IVS5-I IA>G mutant minigene transfected cells. The positions of wild type, +5G>C, I I $\mathrm{A}>\mathrm{G}$, and - IG>T PITX2 protein, and GFP protein, are indicated at the right. C. RNase protection assay (RPA). RNA from the indicated transfections was subjected to RPA with the same probe used in Figure 5, protected products were resolved on a 6\%-8 $\mathrm{M}$ urea polyacrylamide gel, and a phosphorimage was obtained. Correct PITX2c splicing generates a $\sim 206 \mathrm{nt}$ band and GFP generates a $309 \mathrm{nt}$ band. M, ${ }^{32} \mathrm{P}$-labeled pBR322/Mspl markers with sizes indicated on the left; $\mathrm{P}$, undigested probes; mock, RNA from GFP-transfected cells. The positions of correctly spliced and GFP protected products are shown at the right. The asterisks denote artifact bands derived from the GFP probe. The multiple bands for spliced product are likely due to incomplete RNase digestion. Below the lanes is quantitation of splicing relative to WT as assessed by Phosphorlmager analysis.

\section{Discussion}

We report two new families with intronic mutations in the PITX2 gene and give insights into the mechanisms by which these and a previously described intronic mutation may affect PITX2 protein expression and influence development of ARS. A deficiency in normal PITX2 protein was proposed as the major cause of ARS and each of the mutations examined caused RNA splicing defects that would affect PITX2 protein levels or function, consistent with a gene dosage model for development of the syndrome.

Mutation IVS4-1G>T is the most $5^{\prime}$ positioned PITX2 mutation identified to date ([18], [25], this report). This mutation changes the 3 ' intron-terminal $G$ to a $T$ and mutates the terminal "AG" intron junction dinucleotide. The terminal AG dinucleotide is critical for splicing catalysis and it was expected that splicing at the correct site would be abolished. A number of mechanisms for specifying the 3' ss AG have been proposed, including scanning from the branchpoint to the first AG [39], measurement from the branchpoint to the AG [40], or a combination of the AG being in the correct context and an optimal distance from the branchpoint [41]. The next available AG was located immediately 3 ' to the mutated junction and splicing was completely shifted to this site. Because of aberrant splicing, the resulting protein is predicted to contain only the N-terminal 70 amino acids of PITX2 and lack the entire homeodomain and C-terminal region. Extrapo- 
lation of our analysis in tissue culture cells to the patient suggests that the mutant protein would be present at negligible amounts and therefore, the patient's phenotype is most easily explained by haploinsufficiency of wild-type PITX2 protein (50\% of normal). Interestingly, two unrelated patients with mutations at this nucleotide manifest ARS with one extra feature not commonly reported in ARS pedigrees - an anteriorly placed anus (this report; [18]). Also, two previously reported families with IVS4-1G>T and $-1 \mathrm{G}>\mathrm{C}$ substitutions were noted to display a severe form of Axenfeld-Rieger ocular anomaly including aniridia (unfortunately, detailed records were not available for patient 0175 reported here). Whether these features might be truly associated with this type of mutation and are caused by expression of only the N-terminal end of PITX2 remains to be seen.

The second mutation studied was identified in an individual (689) from a family with Axenfeld-Rieger anomaly and normal dental and umbilical development. The mutation is a change at position +5 of the 5 'ss at the downstream border of exon 4 that led to predominant intron retention. This was surprising since exon skipping was the expected outcome. It is possible that our minigene/transfection system does not reflect the outcome in patients, but splice site mutations do result in intron retention at reasonable frequencies [42]. Curiously, the same mutation was previously reported in a family affected with complete ARS [9]. Little protein was generated from the aberrant mRNA and that which is made would be nonfunctional since it is truncated in the homeodomain. Since expression of the mutant allele in transfected cells resulted in 30\% correctly spliced mRNA, the patient might be expected to have a milder phenotype since PITX2 protein would be $\sim 65 \%$ of normal rather than the $50 \%$ expected of haploinsufficiency.

While our study demonstrates that the IVS4+5G>C mutation causes a similar level of intron retention in three tissue culture cell systems, it is curious that two individuals with the same mutation (families 689 and 2) exhibited different phenotypes and have corresponding clinical family histories (Figures $1 \mathrm{~B}$ and 1C)[9]. Unfortunately, patient samples cannot be examined directly, but it is possible that the degree of aberrant splicing differs in these individuals, with a greater amount of aberrant splicing associated with a more severe phenotype. The mutation should alter recognition of the 5 'ss by the core splicing machine, an event that is influenced by numerous positive and negative auxiliary factors whose expression patterns often show cell-type specific and temporal variation [32]. For example, trans-acting splicing activators often promote recognition of exons and correct splicing through interactions with splicing enhancer sequences located in exons. Indeed, purine-rich sequences upstream of the affected PITX2 5'ss resemble splicing enhancer elements that bind the SR protein family of splicing activators [43]. It is possible that genetic background differences influence the levels of one or more of these factors, resulting in differential effects of the IVS4+5G>C mutation on splicing in the two patients. The mutation would manifest as a less severe splicing defect, and thus higher levels of wild-type protein in the patient with the milder phenotype. It is also possible that the putative splicing enhancer elements in exon 4 explain the intron retention outcome by promoting recognition of the exon such that splicing of the upstream intron occurs, but the mutation in the 5' ss abolishes downstream intron splicing. Another possibility is genetic variation in the promoters of PITX2 target genes such that lower levels of PITX2 protein activate them.

The IVS4+5G>C PITX2 mutation represents another demonstration of affected phenotypes associated with a more than 50\% level of normal PITX2 protein. In previous reports, it was argued that some of the PITX2 mutant proteins retain partial function and this fact explains milder ARS phenotypes seen in affected families [19,31]. Another observation emerging from these studies is that human ocular development appears to be the most sensitive to the amounts of PITX2 protein as "mild" mutations allow dental and umbilical development to proceed normally but still have a profound effect on ocular structures, while "severe" mutations result in more complex ocular defects (this report; [19,20,30,31]).

The third mutation (IVS5-11A>G) reported in two families with classic ARS is an $A>G$ mutation located eleven nucleotides upstream of the 3 ' ss associated with exon 5 $[9,21]$. An important determinant of 3 'ss strength is the polypyrimidine tract that lies between the branch point and the splice junction [32]; purine interruptions decrease 3 'ss quality. The IVS5-11A $>$ G mutation would not be expected to alter the strength of the 3 ' ss but the mutation does create a new "AG" dinucleotide and that could compete with the authentic one $11 \mathrm{nt}$ downstream. As discussed above, this new AG could be recognized by scanning due to the fact that a pyrimidine tract is located upstream or by a mechanism similar to that described in Coffin-Lowry syndrome whereby the authentic AG in the RSK2 gene is involved in the first steps of splicing but the new AG is utilized in the second step as the splice junction [44]. Regardless, a complete shift in IVS5-11A>G minigene RNA splicing to the new site was observed and resulted in expression of a truncated protein that lacks a functional homeodomain. ARS phenotype in these families included classic ocular, dental and umbilical features (this report; Dr. Nishimura, personal communication) and can be explained by haploinsufficiency although the possibility that the mutant protein provides an additional effect cannot be excluded. 


\section{Conclusion}

In summary, we provide the first direct evidence that PITX2 intronic mutations cause splicing defects. We propose that the molecular defect in patients harboring these mutations is at the level of mRNA splicing such that the level of functional protein is reduced. Furthermore, the extent of the splicing defect observed in our system generally correlates with phenotypic severity, which supports the PITX2 gene dosage model for Axenfeld-Rieger syndrome. Because the mutations described here affect splicing of the last two exons that are common to all isoforms, similar splicing defects would be expected for all PITX2 transcripts. The gene dosage model was initially proposed based on in vitro studies that demonstrated an association between partial function for some mutant PITX2 proteins and milder phenotypes. Here, we report a splicing mutation (IVS4+5G>C) that results in production of some normal mRNA/protein from a minigene, which suggests an association between elevated levels of normal PITX2 ( $65 \%$ vs. $50 \%$ ) and milder human phenotypes. We also suggest that the phenotypic outcome may be dependent on secondary factors/genetic background of mutation carriers.

\section{Competing interests}

The author(s) declare that they have no competing interests.

\section{Authors' contributions}

NLM carried out the molecular studies in Figures 2 through 6 and participated in drafting the manuscript.

WLMA was involved in clinical evaluation of the ARS patients and provided human samples and clinical material for the study.

JCM provided collection of human patient and control samples and participated in genetic analyses.

EVS identified human mutations reported in the study, conceived and participated in the design of the study and helped draft the manuscript.

MTM conceived and participated in the design of the study, coordinated the molecular studies, helped draft the manuscript, and obtained study funding.

\section{Acknowledgements}

We are grateful to members of the McNally and Semina labs for helpful comments on the manuscript, Dr. Watsky for generously providing corneal cell lines and Dr. Sakazume for help with their culture and transfection experiments. We also would like to thank families for participation in this study. This work was supported by Public Health Service Grant ROI CA78709 from the National Cancer Institute to MTM, and awards EYI3606 and EYOI55I8 from the National Eye Institute to EVS.

\section{References}

I. Axenfeld T: Embryotoxon corneae posteris. Ber Dtsch Ophthalmol Ges 1920, 42:381-382.

2. Rieger $\mathrm{H}$ : Beitraege zur kenntnis seltener und entrundung der pupille. Albrecht von Graefes Arch Klin Exp Ophthalmol 1935, 133:602-635.

3. Rieger $\mathrm{H}$ : Verlagerung und schitzform der pupille mit hypopasie des irisvordblattes. Z Augenheilk 1934, 84:98-99.

4. Shields MB, Buckley E, Klintworth GK, Thresher R: AxenfeldRieger syndrome. A spectrum of developmental disorders. Surv Ophthalmol 1985, 29(6):387-409.

5. Alward WL: Axenfeld-Rieger syndrome in the age of molecular genetics. Am J Ophthalmol 2000, I30(I): I07-II5.

6. Grosso S, Farnetani MA, Berardi R, Vivarelli R, Vanni M, Morgese G, Balestri P: Familial Axenfeld-Rieger anomaly, cardiac malformations, and sensorineural hearing loss: a provisionally unique genetic syndrome? Am J Med Genet 2002, I I I (2): 182-186.

7. Mammi I, De Giorgio P, Clementi M, Tenconi R: Cardiovascular anomaly in Rieger Syndrome: heterogeneity or contiguity? Acta Ophthalmol Scand 1998, 76(4):509-5I2.

8. Jorgenson RJ, Levin LS, Cross HE, Yoder F, Kelly TE: The Rieger syndrome. Am J Med Genet I978, 2(3):307-3I8.

9. Semina EV, Reiter R, Leysens NJ, Alward WL, Small KW, Datson NA, Siegel-Bartelt J, Bierke-Nelson D, Bitoun P, Zabel BU, Carey JC, Murray JC: Cloning and characterization of a novel bicoid-related homeobox transcription factor gene, RIEG, involved in Rieger syndrome. Nat Genet 1996, I 4(4):392-399.

10. Phillips JC, del Bono EA, Haines JL, Pralea AM, Cohen JS, Greff LJ, Wiggs JL: A second locus for Rieger syndrome maps to chromosome I3q I4. Am J Hum Genet 1996, 59(3):613-619.

II. Nishimura DY, Swiderski RE, Alward WL, Searby CC, Patil SR, Bennet SR, Kanis AB, Gastier JM, Stone EM, Sheffield VC: The forkhead transcription factor gene FKHL7 is responsible for glaucoma phenotypes which map to 6p25. Nat Genet I998, I9(2): |40-|47.

12. Kume T, Deng KY, Winfrey V, Gould DB, Walter MA, Hogan BL: The forkhead/winged helix gene $\mathrm{MfI}$ is disrupted in the pleiotropic mouse mutation congenital hydrocephalus. Cell I998, 93(6):985-996.

13. Mears AJ, Jordan T, Mirzayans F, Dubois S, Kume T, Parlee M, Ritch R, Koop B, Kuo WL, Collins C, Marshall J, Gould DB, Pearce W, Carlsson P, Enerback S, Morissette J, Bhattacharya S, Hogan B, Raymond $V$, Walter MA: Mutations of the forkhead/winged-helix gene, FKHL7, in patients with Axenfeld-Rieger anomaly. Am J Hum Genet 1998, 63(5): I 316-1328.

14. Mirzayans F, Gould DB, Heon E, Billingsley GD, Cheung JC, Mears AJ, Walter MA: Axenfeld-Rieger syndrome resulting from mutation of the FKHL7 gene on chromosome 6p25. Eur J Hum Genet 2000, 8(I):7I-74.

15. Riise R, Storhaug K, Brondum-Nielsen K: Rieger syndrome is associated with PAX6 deletion. Acta Ophthalmol Scand 2001, 79(2):20l-203.

16. Kulak SC, Kozlowski K, Semina EV, Pearce WG, Walter MA: Mutation in the RIEG I gene in patients with iridogoniodysgenesis syndrome. Hum Mol Genet 1998, 7(7): I I I3-I I I 7.

17. Doward W, Perveen R, Lloyd IC, Ridgway AE, Wilson L, Black GC: A mutation in the RIEG I gene associated with Peters' anomaly. J Med Genet 1999, 36(2): I52-155.

18. Perveen R, Lloyd IC, Clayton-Smith J, Churchill A, van Heyningen V, Hanson I, Taylor D, McKeown C, Super M, Kerr B, Winter R, Black GC: Phenotypic variability and asymmetry of Rieger syndrome associated with PITX2 mutations. Invest Ophthalmol Vis Sci 2000, 4 I(9):2456-2460.

19. Priston M, Kozlowski K, Gill D, Letwin K, Buys Y, Levin AV, Walter $M A$, Heon E: Functional analyses of two newly identified PITX2 mutants reveal a novel molecular mechanism for Axenfeld-Rieger syndrome. Hum Mol Genet 2001, I0(16):1631-1638.

20. Saadi I, Semina EV, Amendt BA, Harris DJ, Murphy KP, Murray JC, Russo AF: Identification of a dominant negative homeodomain mutation in Rieger syndrome. J Biol Chem 200I, 276(25):23034-2304I.

21. Borges AS, Susanna RJ, Carani JC, Betinjane AJ, Alward WL, Stone EM, Sheffield VC, Nishimura DY: Genetic analysis of PITX2 and FOXCI in Rieger Syndrome patients from Brazil. J Glaucoma 2002, I I (I):5 I-56. 
22. Phillips JC: Four novel mutations in the PITX2 gene in patients with Axenfeld-Rieger syndrome. Ophthalmic Res 2002, 34(5):324-326.

23. Wang $\mathrm{Y}$, Zhao $\mathrm{H}$, Zhang $X$, Feng $\mathrm{H}$ : Novel identification of a four base-pair deletion mutation in PITX2 in a Rieger syndrome family. J Dent Res 2003, 82(I 2): I008-I0I2.

24. Brooks BP, Moroi SE, Downs CA, Wiltse S, Othman MI, Semina EV, Richards JE: A novel mutation in the PITX2 gene in a family with Axenfeld-Rieger syndrome. Ophthalmic Genet 2004 25(I):57-62

25. Lines MA, Kozlowski K, Kulak SC, Allingham RR, Heon E, Ritch R, Levin AV, Shields MB, Damji KF, Newlin A, Walter MA: Characterization and prevalence of PITX2 microdeletions and mutations in Axenfeld-Rieger malformations. Invest Ophthalmol Vis Sci 2004, 45(3):828-833.

26. Xia K, Wu L, Liu X, Xi X, Liang D, Zheng D, Cai F, Pan Q, Long Z, Dai H, Hu Z, Tang B, Zhang Z, Xia J: Mutation in PITX2 is associated with ring dermoid of the cornea. I Med Genet 2004, 4 I (I2):el29.

27. Alward WL, Semina EV, Kalenak JW, Heon E, Sheth BP, Stone EM, Murray JC: Autosomal dominant iris hypoplasia is caused by a mutation in the Rieger syndrome (RIEG/PITX2) gene. Am J Ophthalmol 1998, I 25( I):98-100.

28. Cox CJ, Espinoza HM, McWilliams B, Chappell K, Morton L, Hjalt TA, Semina EV, Amendt BA: Differential regulation of gene expression by PITX2 isoforms. J Biol Chem 2002, 277(28):2500 I-250 I0.

29. Holmberg J, Liu CY, Hjalt TA: PITX2 gain-of-function in Rieger syndrome eye model. Am J Pathol 2004, I 65(5): I633-I64 I.

30. Kozlowski $\mathrm{K}$, Walter MA: Variation in residual PITX2 activity underlies the phenotypic spectrum of anterior segment developmental disorders. Hum Mol Genet 2000 9( I 4):2। $31-2139$

31. Espinoza HM, Cox CJ, Semina EV, Amendt BA: A molecular basis for differential developmental anomalies in Axenfeld-Rieger syndrome. Hum Mol Genet 2002, I I (7):743-753.

32. Burge CB, Tushchl TH, Sharp PA: Splicing of precursors to mRNAs by the Spliceosome. In The RNA World 2nd edition. Edited by: Gesteland RF, Cech T, Atkins JF. Cold Spring Harbor, New York, Cold Spring Harbor Laboratory Press; 1999:525-560.

33. Ausubel FM, Brent R, Kingston RE, Moore DD, Seidman JG, Smith JA, Struhl K: Current protocols in molecular biology. John Wiley \& Sons; 1998.

34. McNally LM, McNally MT: An RNA splicing enhancer-like sequence is a component of a splicing inhibitor element from Rous sarcoma virus. Mol Cell Biol I998, I 8(6):3 I03-3 I I I.

35. Amendt BA, Semina EV, Alward WL: Rieger syndrome: a clinical, molecular, and biochemical analysis. Cell Mol Life Sci 2000 57(I I): I652-I666.

36. Arakawa $H$, Nakamura $T$, Zhadanov $A B$, Fidanza $V$, Yano $T$, Bullrich F, Shimizu M, Blechman J, Mazo A, Canaani E, Croce CM: Identification and characterization of the ARPI gene, a target for the human acute leukemia ALLI gene. Proc Natl Acad Sci U S A 1998, 95(8):4573-4578.

37. Abril JF, Castelo R, Guigo R: Comparison of splice sites in mammals and chicken. Genome Res 2005, I 5(I): I I I-II9.

38. Griffith $M$, Osborne R, Munger R, Xiong X, Doillon CJ, Laycock NL, Hakim M, Song Y, Watsky MA: Functional human corneal equivalents constructed from cell lines. Science 1999 286(5447):2|69-2|72.

39. Chen S, Anderson K, Moore MJ: Evidence for a linear search in bimolecular 3' splice site AG selection. Proc Natl Acad Sci U S A 2000, 97(2):593-598.

40. Chiara MD, Palandjian L, Feld Kramer R, Reed R: Evidence that U5 snRNP recognizes the 3 ' splice site for catalytic step II in mammals. Embo J 1997, I 6(I5):4746-4759.

41. Chua K, Reed R: An upstream AG determines whether a downstream AG is selected during catalytic step II of splicing. Mol Cell Biol 200I, 2 I(5): I509-I5I4.

42. Nakai K, Sakamoto H: Construction of a novel database containing aberrant splicing mutations of mammalian genes. Gene 1994, I4I(2): I71-177.

43. Graveley BR: Sorting out the complexity of SR protein functions. RNA 2000, 6(9): $1197-1211$.

44. Zeniou M, Gattoni R, Hanauer A, Stevenin J: Delineation of the mechanisms of aberrant splicing caused by two unusua intronic mutations in the RSK2 gene involved in CoffinLowry syndrome. Nucleic Acids Res 2004, 32(3): I 2 | 4- I 223

\section{Pre-publication history}

The pre-publication history for this paper can be accessed here:

http://www.biomedcentral.com/1471-2350/7/59/prepub
Publish with BioMed Central and every scientist can read your work free of charge

"BioMed Central will be the most significant development for disseminating the results of biomedical research in our lifetime. "

Sir Paul Nurse, Cancer Research UK

Your research papers will be:

- available free of charge to the entire biomedical community

- peer reviewed and published immediately upon acceptance

- cited in PubMed and archived on PubMed Central

- yours - you keep the copyright
BioMedcentral 